\title{
Improving the quality of products created by additive technologies on the basis of tig welding
}

\author{
O. F. Salenko ${ }^{1}$ • A. O. Kostenko ${ }^{1}$ - D. O. Tsurkan ${ }^{1} \bullet$ O. V. Samoilenko ${ }^{1} \bullet$ \\ O. O. Chencheva ${ }^{2} \bullet$ V. T. Shchetinin ${ }^{2}$
}

Received: 20 April 2021 / Accepted: 24 May 2021

\begin{abstract}
The paper deals with the issues of obtaining the minimum waviness of surfaces formed by additive processes of TIG welding. It is known that the geometric parameters of the melt bead, which form a reproducible workpiece layer by layer, are determined by both the energy and kinematic characteristics of the process. In this case, the laying of the rollers occurs with optimal overlap, as a result of which it is possible to achieve the maximum density of the model, however, with the simultaneous appearance of a certain waviness due to thermodynamic phenomena in the melt bath. The proposed model of the formation of a bead of melt, the use of which made it possible to establish the rational conditions for laying out the layers. Experimental studies of the process of argon-arc surfacing of models of a given, regression equations for determining the controlled waviness parameter are obtained.

It is shown that the waviness parameter is influenced by dynamic phenomena and wave processes that develop under the action of a system of forces during the formation of a melt bead. An improvement in the quality of products is seen in the optimization of the methods offorming the rollers, in ensuring the dynamic stability of the movement of the working head, ensuring the appropriate overlap of the trajectories of movement along the layers of the layout by an amount of $0.5 e$, establishing a rational arc length, and maintaining the dynamic stability of the arc burning.

The response surfaces of the objective functions in the planes of the process parameters are constructed, which provide a clear illustration of the dependence of the controlled geometric parameters on the welding modes.
\end{abstract}

Keywords: TIG welding, additive processes, quality, shape accuracy, surface layer.

\section{Introduction}

The development of additive technologies based on the use of electric arc and wire (WAAM), known as the method of direct energy deposition (DED-arc), due to the need to increase the efficiency of production of engineering structures. Ability to produce blanks similar in shape to the finished product without involving complex additional tools, molds and forging equipment provides high potential for significant reduction of costs and time for technological preparation of production, increase the efficiency of materials (by reducing its conversion in shavings at the subsequent machining) and reduction of expenses for material stocks at production in small parties to order.

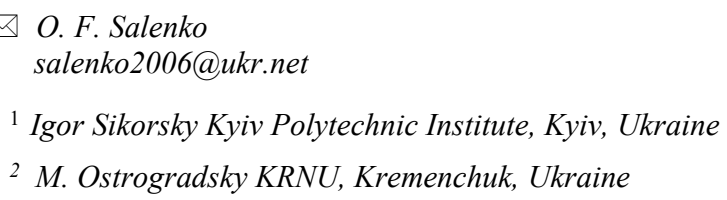

\section{Actuality}

First patented in 1920 [1], WAAM is the oldest and simplest process for the production of additives (AM) (known as 3D printing). Using wire as a raw material, the main process is used for local repair of damaged or worn parts $[2,3]$, as well as for the restoration and repair of large parts and pressure vessels in recent decades [4]. The advent of appropriate software for automated design and manufacture (CAD / CAM) has made AM more common and applicable [5], outlined new horizons and directions for the development of such processes. WAAM is one of the most promising among them. With a resolution of approximately $1.0 \mathrm{~mm}$ and a deposition rate of 1 to $10 \mathrm{~kg} / \mathrm{h}$ (depending on the arc source, $[6,7]$ ), the WAAM process has taken a niche as an additional, procurement; however, under certain circumstances, it can be high-precision [8], when using a laser that reproduces the workpiece in a protective gas environment [9] or vacuum [10]. 
Another variety is electron beam systems [11]. The latter processes are slower [12], especially in comparison with less accurate systems of multi-arc plasma structures [13].

WAAM manipulation systems are mostly of one of two types: robotic manipulators or machine tools. For today, some commercial machines and robotic WAAM systems are available, which are the market leaders in integrated systems and include some very powerful manipulation systems and CAD / CAM software: this, in particular, [14], [15]. However, almost any three-coordinate manipulator or arm robot and arc welding source can be combined to create an entry-level WAAM system, as shown in [16].

The market also offers different types of power supplies and to some extent the material used will determine the chosen process of arc deposition. For example, titanium alloys are typically applied with a more stable arc transmitted by a fusible electrode process (TIG process) or plasma, while most other materials are deposited by a MIG / MAG process (melting in a shielding gas medium).

The new range of low-heat MIG / MAG systems is particularly suitable for WAAM. In fig. 1 shows one of the systems used for WAAM in TWI [17]; It is the industry standard for robotic welding equipment, which is also used for AM projects. Adaptation of AM for this system includes modification of the turntable for constant controlled rotation, modified control software, increased thermal control and wear-resistant parts in the power supply, which allow to ensure long-term operation of the arc [18].

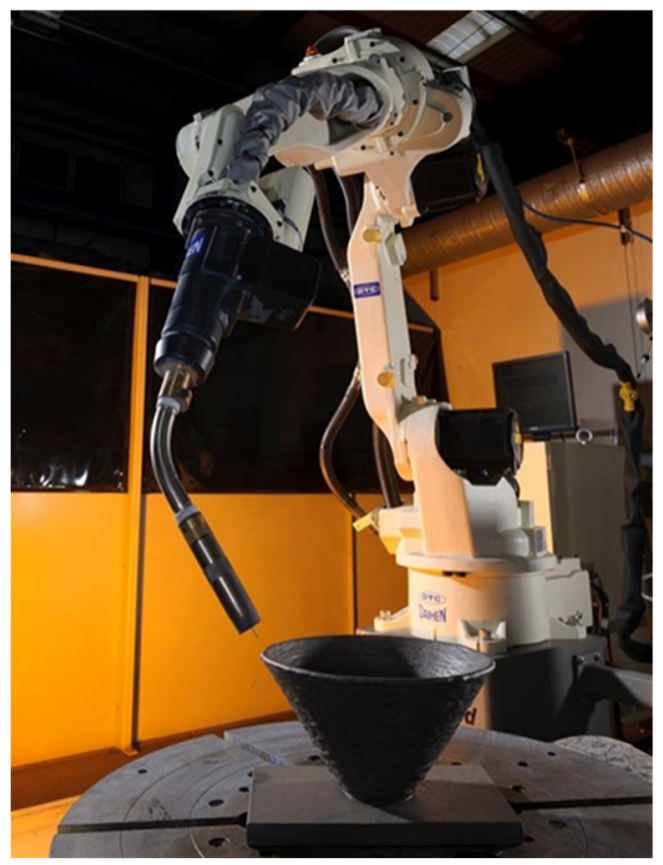

Fig. 1. WAAM operating system (for [17])

One more interesting offer is an inexpensive printer for the WAAM process, built on the basis of a multi-link FDM printer system, but with mirrored working rods [19], Fig. 2.

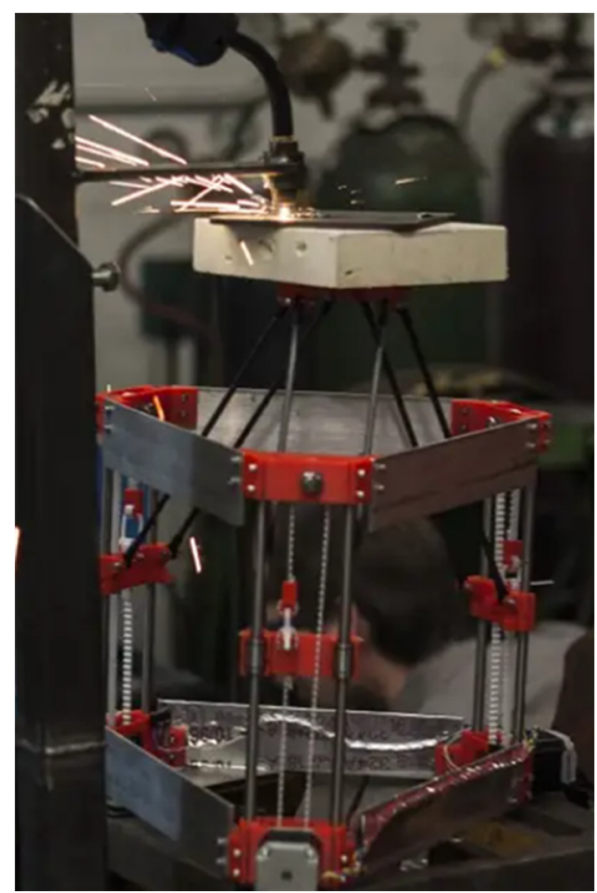

Fig. 2. Inexpensive 3-D printer to implement the WAAM process

Machine-based systems, where deposition equipment has been integrated, have additional potential [20], which allows to combine AM processes and cutting processes (SM) in layers, allowing to create and implement functions that have no analogues. AM / SM hybrid machines based on laser powder prototyping are available [21]. The development of hybrid WAAM / SM systems is still ongoing, so we are currently preparing to introduce new equipment concepts on the market [22]. WAAM has significant potential to reduce costs and lead times for medium and large engineering components of medium complexity. Parametric and functional design of WAAM can provide some topological optimization, and the choice of wire allows you to perform additional optimization of material and multicomponent alloys, maximally adapting them to special operating conditions, realizing the synergy of actions when creating a finished part [23]. If AM is combined with a processing platform, it becomes possible to create some otherwise impossible elements and details [24]. Thus, the theory of functional approach to processing technologies, covered in $[24,25]$, is further developed.

WAAM is not currently a fully automated process; until fully operational commercial AMCAD / CAM software becomes available, the part model is refined practically manually, and, of course, certain operator skills are required. The resulting surface (ripple) WAAM requires cutting to achieve geometric requirements and the appropriate quality of the surface layer. However, the volume of material, that can be removed can only be $1 \mathrm{~mm}$; it does not increase with the size of the part, so the efficiency of 


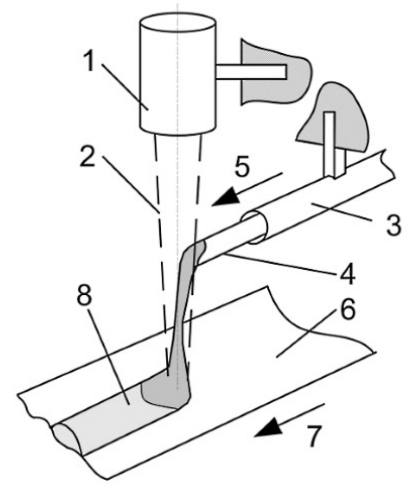

$a$

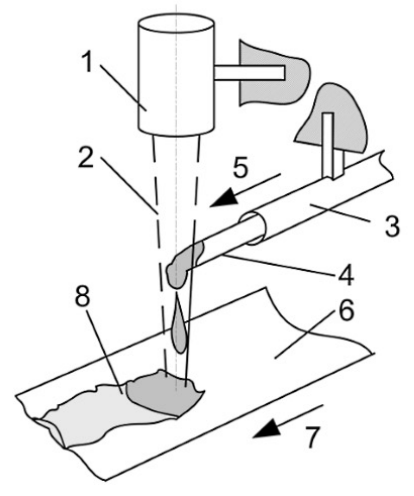

$b$

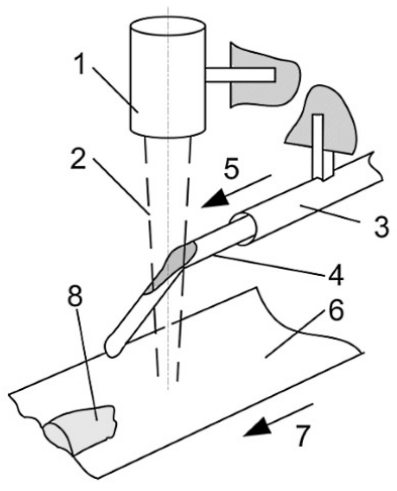

$c$

Fig. 3. Principles and scheme of additive production using additive material by means of high-energy heating: $a$ - with jet transfer of metal; $b$ - with drip transfer; in - mode with insufficient to complete melting of energy; 1 - source of high-energy heating (electronic gun, laser, electric arc); 2 - high-energy column; 3 - feed mechanism; 4 - additive material; 5 - direction of supply; 6 - molded product; 7 - direction of movement of the product; 8 formed array of parts (according to [27])

the material actually increases with increasing parts. Another problem is a certain emptiness of the structure, inherent in all AM processes, the reduction of which requires additional efforts to algorithmize the process of moving the working head [26]. That is why the most appropriate use of WAAM in the aerospace industry, where the ability to manufacture large metal parts from light materials (in particular, titanium alloys) is the main advantage of the WAAM method.

Therefore, the problem of identifying ways and methods to improve the quality of reproduction of WAAM workpieces by the process, in particular, reducing the waviness, reducing the hollowness of the finished product, is really actual and relevant today.

Purpose: to identify conditions and reduce the ripple of the surface layer during the reproduction of workpieces by WAAM.

Research materials. Additive processes using the phenomena of metal melting by an external heat source (electric arc, electron beam, laser) are based on the principles of forming a surface globule caused by melting a drop of metal flowing from the electrode or formed by introducing additive metal into the thermal zone. This is noted, in particular, in [27], and shown in Fig. 3. If the system is given working movements, the globules of the filler metal will form a roller, the size of which will be determined by a number of parameters and technological factors. Since the reproduction of a given three-dimensional object, its generation occurs in layers, by creating bands lying in one plane, ensuring product quality, its density, as well as the parameters of the surface layer (including surface waviness) is seen in such a calculation of metal, which is formed by globules the roller will have the correct geometric shape, and the roller of the next layer should fill the gap between the rollers of the previous layer as completely as possible.
On the one hand, in WAAM the formation of globules occurs almost continuously, with constant remelting, because the electric arc forms a high-temperature zone of influence. This phenomenon is negative for 3-d prototyping, because it is impossible to achieve high accuracy of products. On the other hand, the combustion of the arc and the active melting of not only the filler material, but also the basis for laying, requires consideration of hydrodynamic phenomena in the melt bath, under the action of which the profile of the laid roller is formed.

We assume that the melting of the filler material is blown simultaneously with the heating of the working area by an electric arc, Fig. 4. In this case, according to [26], it is advisable to maintain the arc with direct current, with direct polarity (with a cathode spot at the end of the electrode and the expected temperature up to $3200{ }^{\circ} \mathrm{C}$ ), which allows to form a more compact thermal effect on the surface and get smaller melt droplets.

Due to the action of an electric arc, the balance of forces in the melt zone can be represented according to [23], Fig. 3.

The welding bath is formed due to the influence of the arc, the action of drops of molten metal vapors and reaction forces. There is a movement of liquid metal in the melting zone, to which drops of molten electrode are introduced. During melting of metals by an electron beam, the motion is observed from the front wall of the bath along the seam, with partial evaporation of the metal and with the maintenance of thermocapillary forces. According to [22], these forces are a consequence of the difference in surface tension forces, which are caused by the temperature gradient between the melt and solidification zone.

The movement of liquid metal in the region of the arc passage occurs around the zone of influence (perpendicular to the axis of the electrode) in the direction from the melting zone and in the direction of the arc-counterclockwise [28]. Thermocapillary convection due to the tem- 


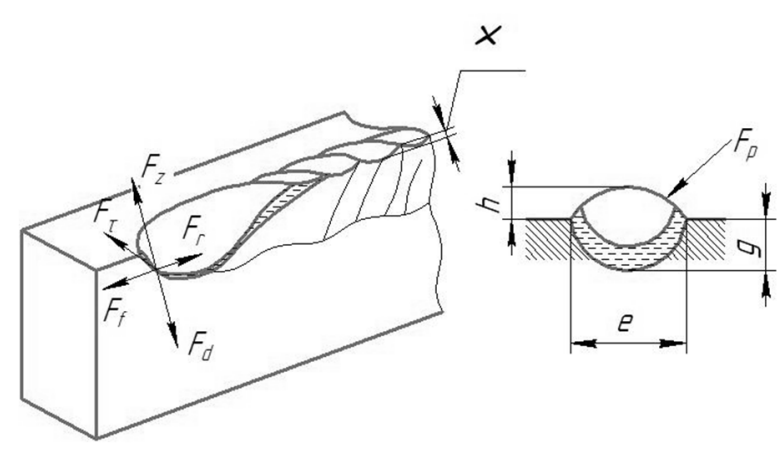

Fig. 4. Power balance of the melt bath: $\mathrm{F}_{f}$ - force acting on the front of the melt; $\mathrm{F}_{z}$ - displacement force of the liquid metal; $F_{\tau}$ - tangential forces in the melt bath due to the movement of the electrode; $F_{d}$ - force of an electric arc; $F_{p}$ - surface tension forces during solidification of liquid metal; $F_{r}$ - tangential surface forces, which affect the metal melting

perature gradient is known as the Maragoni effect [19].

According to the testimony [27], waves phenomena, which occur in the melt zone due to the action of the forces of the melt zone and temperature effects at the time of arc combustion.

The formation of the surfacing roller as a fragment of the 3-d model will occur in accordance with Figs. 5, if the linear movement will be used, $5, b$ - rotating will be exist.

If the intensity of a point heat source (electric arc) obeys Gauss's law with its own intensity $I(w)=I_{0} \exp \left(-w^{2} / w_{G}^{2}\right)$, where $I_{0}$ - the intensity of the heat on the axis of the electric arc , $w$ - flowing radius; $w_{\mathrm{G}}-$ the radius at which the radiation intensity decreases $e$ times, the considerations will be as follows. form [26]

The known equation of non-uniform heating has the

$$
\frac{\partial T}{\partial t}=\alpha\left(\frac{\partial^{2} T}{\partial x^{2}}+\frac{\partial^{2} T}{\partial y^{2}}+\frac{\partial^{2} T}{\partial z^{2}}\right)
$$

boundary conditions on the surface from the action of the source $-\left.k \frac{\partial T}{\partial z}\right|_{z=0}=q(x, y, t)$, where $q=q_{0} 1, q_{0}$ reflects the density of heat from the supplied energy, $k$ - thermal conductivity of the material; z-axis is perpendicular to the surface and directed to the depth of the material. For a stationary system, the heat distribution will be:

$T(x, z, t)=\frac{q(x) r^{2}}{\lambda}\left(\frac{a}{\pi}\right)^{1 / 2} \int_{0}^{t} \frac{P(t-\tau) \exp \left[\frac{z^{2}}{4 a t}-\frac{x^{2}}{4 a \tau}\right]}{\sqrt{\tau}\left(4 a \tau+r^{2}\right)} d \tau$,

where $\lambda$ - thermal conductivity; $a$ - thermal diffusion of

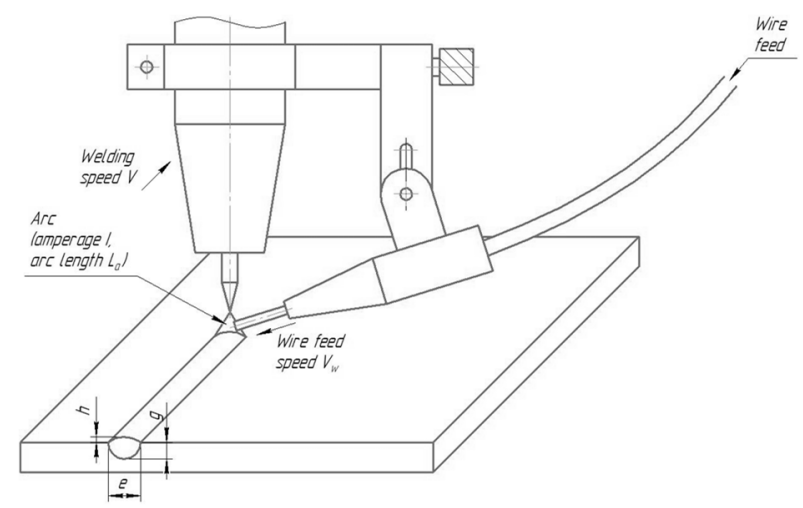

$a$
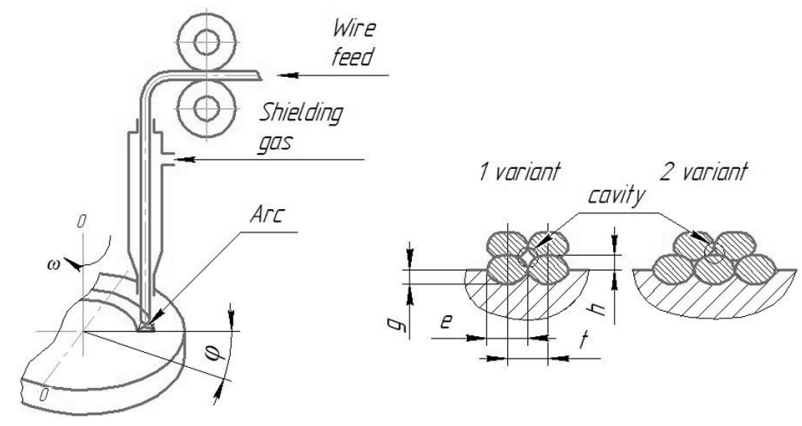

$b$

Fig. 5. Scheme of formation of the surfacing roller $(a)$ and the process of model reproduction in the study $(b)$

the material of the workpiece; $t$ - current time; $P$ - electric arc power.

The temperature on the surface of a semi-infinite body at a point with coordinates $(x, y, z)$, provided the heat source, moves with velocity $v$, as well as ignoring heat loss from the surface will be:

$$
\begin{aligned}
& \bar{T}=\frac{16}{\sqrt{\pi}} \int_{0}^{\infty} \frac{1}{\sqrt{\left(c^{\prime 2}+\tau^{2}\right)\left(b^{2}+\bar{\tau}^{2}\right)}} \times \\
& \times \exp \left[-\frac{\left(2 \bar{x}^{2}+\bar{v}^{\prime} \tau\right)^{2}}{4\left(\bar{c}^{2}+\bar{\tau}^{2}\right)}-\frac{\bar{y}^{2}}{\bar{b}^{2}+\bar{t}^{2}}-\frac{\bar{z}^{2}}{\bar{t}^{2}}\right] d \tau,
\end{aligned}
$$

where $\quad \bar{T}=16 \sqrt{\pi K r} T / P A_{0} ; \quad \bar{v}=v_{r} / 2 a$;

$$
\begin{aligned}
& \bar{x}^{\prime}=\frac{x}{r} ; \bar{y}^{\prime}=\frac{y}{r} ; \bar{z}^{\prime}=\frac{z}{r} ; \\
& \bar{c}^{\prime}=\frac{c}{r} ; \bar{b}^{\prime}=\frac{b}{r} ; r^{2}=c b ;
\end{aligned}
$$

$A_{0}$ - scattering capacity of the workpiece; $\mathrm{P}$ - heat source power; $\mathrm{b}, \mathrm{c}$ - parameters of energy density distribution in the cross section of thermal influence. The change in temperature will be determined by the ratio: 


$$
\begin{aligned}
& T(x, y, z, t)=\frac{P}{\pi \frac{1}{2} \rho c} \times \\
& \times \int_{0}^{t} \frac{e^{\frac{(x-v(t-z))^{2}}{4 \alpha \tau+A^{2}} \frac{y^{2}}{4 \alpha \tau+B^{2}}}}{\left[\left(4 \alpha \tau+A^{2}\right)\left(4 \alpha \tau+B^{2}\right) \alpha \tau\right]^{1 / 2}} \times \\
& \times\left[e^{-\frac{z^{2}}{4 \alpha \tau}}-\eta(\pi \alpha \tau)^{1 / 2} \times\right. \\
& \left.\times \operatorname{erfc}\left(\frac{z}{2(\alpha \tau)^{1 / 2}}+\eta(\alpha \tau)^{1 / 2}\right) \times e^{\eta z+\eta^{2} \alpha \tau}\right] d r
\end{aligned}
$$

$x, y, z$ - coordinates; $t$ - time; $\eta$ - heat transfer coefficient from the surface of the workpiece; $\alpha$ - thermal conductivity; A and B - larger and smaller axes of the heating area.

The depth of heating $\delta$ determine the equation

$$
\begin{aligned}
& T(t)=T_{\max }-\frac{q_{l} \delta}{\lambda}\left[\frac{2}{\sqrt{\pi}} \frac{\sqrt{a(t-\tau)}}{\delta}+\right. \\
& \left.+\exp \left(\frac{a(t-\tau)}{\delta^{2}}\right) \operatorname{erf} c\left(\frac{\sqrt{a(t-\tau)}}{\delta}\right)\right]
\end{aligned}
$$

The energy balance, taking into account the melt of the material and its partial evaporation, will take the form

$$
P(t) d t=\rho \cdot L_{u} \pi \cdot \tau^{2}(t) d h+\rho \cdot L_{n л} \cdot 2 \pi \cdot \tau(t) h(t) d r
$$

where the first term is the energy expended on evaporation and the second is the energy expended on melting. Then the heat distribution with a fixed electrode corresponds to Fig. 6, a, and the seam profile - Fig. 6, $b$.

The dynamics of the movement of the working body along the teaching surface was modeled by known relations that describe the behavior of a mechanical system with concentrated masses on elastic-elastic bonds.

Mathematical modeling of the surfacing process allowed us to conclude that in addition to the feed factor of the filler metal (expressed through the speed of the wire $v_{n n}$ ), the parameters of the roller are influenced by electrical characteristics of the arc, in particular, current $I$, surface conditions $\left(v_{\mathrm{e}}\right)$; the wavyness of the seam $\chi, \chi=h_{\max }-h_{\min }$, $\mathrm{mm}$, is also determined by the surface where the material is laid. Thus, when laid out on a flat base, the undulation $\chi$ is formed due to the manifestation of dynamic phenomena of the supply system, as well as the pulsating action of the electric arc, Fig. 6, $b$; in the future, the base, which already has a non-planarity, leads to an increase in undulation and under certain conditions can cause a violation of the combustion of the arc. This requires additional study of the phenomena of arc combustion in conditions where the base is not flat, but has the initial spatial deviations; The variant of teaching also has essential value on geometrical parameters of the platen, fig. $5, b$.

Used equipment. To establish the patterns of formation of the surfacing roller in the process of reproducing a given 3-d model used a manipulation system of the machine model 6R13F3 with CNC system NC210 and the electric arc was created using a power supply Fronius Magicwave 3000 , which allowed at a voltage $U=10,1-22 \mathrm{~V}$ to provide a current $I=155-215 \mathrm{~A}$. As an additive used wire $\varnothing 3,0 \mathrm{~mm}$ Titanium Grade 5; he electrode was set at the optimal distance from the surface $L^{\prime}=3-7 \mathrm{~mm}$, its diameter $\varnothing 2,5 \mathrm{~mm}$. Shielding gas-argon.

Discussion of the obtained results. To obtain the regression dependences that determine the shape of the seam, as well as to predict the accuracy parameters of the additive product, denote its geometric characteristics, respectively, Fig. 5, $a$ : $e$-width of the weld, $h$ - height, $g$ - depth of penetration. Deterministic-statistical models of seam shape for mechanized welding in shielding gases
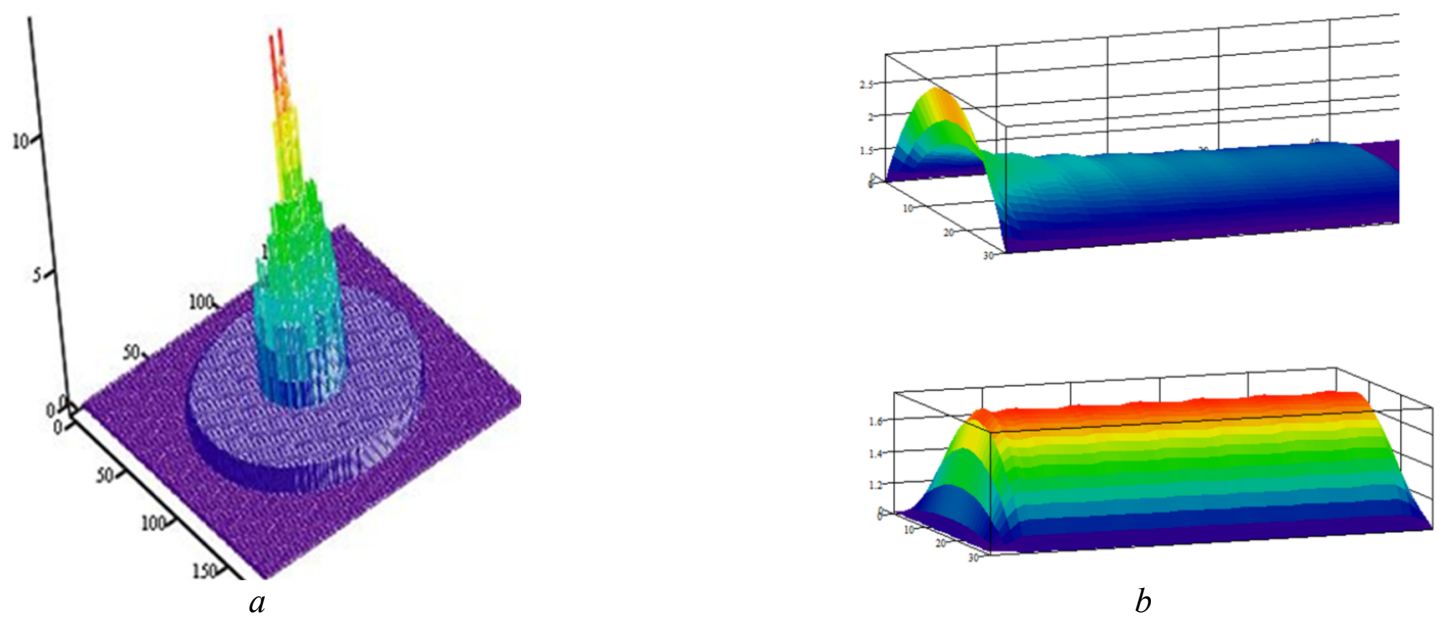

Fig. 6. Diagram of heating the surface with a stationary heat source $(a)$ and the formation of the surfacing roller when laying on a flat base $(b)$ 
with fusible filler wire for the case of fig. 5, a) namely under the condition of a linear flat seam according to [27] have the form:

$$
\begin{gathered}
h=\frac{v_{w}^{1,465} d_{w}^{0,92}}{V^{1,9} d_{e}^{0,078} I^{0,12} L_{a}^{0,05}} ; \\
e=\frac{I^{0,584} L_{a}^{0,433} V_{w}^{0,095} d_{w}^{0,010}}{V^{0,832} d_{e}^{0,782}} ; \\
g=\frac{I^{0,659} V_{w}^{0,247} d_{w}^{0,02}}{V^{0,851} d_{e}^{2,587} L_{a}^{0,415}} ;
\end{gathered}
$$

where $v_{w}$ - wire feed speed, $\mathrm{mm} / \mathrm{s} ; d_{w}$ - diameter of the filler wire, $\mathrm{mm}, v-$ arc speed, $\mathrm{mm} / \mathrm{min} ; d_{e}$ - electrode diameter, $\mathrm{mm} ; I$ - amperage, A; $L_{a}-$ arc length, $\mathrm{mm}$.

Analysis of the obtained models in the form of static expressions of regression equations shows that they reflect the deterministic dependences of the weld size on the main modes of argon arc welding and do not contradict the existing notion of weld formation. However, to teach the circular seam and reproduce the three-dimensional model, it is necessary to adjust the corresponding coefficients; in addition, the corresponding models in the first stage can be in the form of linear functions; in addition to relations (3), there must be another equation that takes into account the wavy surface of the seam $\chi$ So,

$$
\begin{aligned}
& \mathrm{h}=\mathrm{f}\left(\mathrm{V}_{\mathrm{w}}, \mathrm{d}_{\mathrm{w}}, \mathrm{V}, \mathrm{I}, \mathrm{d}_{\mathrm{e}}, \mathrm{L}_{\mathrm{a}}\right) \\
& \mathrm{e}=\mathrm{f}\left(\mathrm{V}_{\mathrm{w}}, \mathrm{d}_{\mathrm{w}}, \mathrm{V}, \mathrm{I}, \mathrm{d}_{\mathrm{e}}, \mathrm{L}_{\mathrm{a}}\right) \\
& \mathrm{g}=\mathrm{f}\left(\mathrm{V}_{\mathrm{w}}, \mathrm{d}_{\mathrm{w}}, \mathrm{V}, \mathrm{I}, \mathrm{d}_{\mathrm{e}}, \mathrm{L}_{\mathrm{a}}\right) \\
& \chi=\mathrm{f}\left(\mathrm{V}_{\mathrm{w}}, \mathrm{d}_{\mathrm{w}}, \mathrm{V}, \mathrm{I}, \mathrm{d}_{\mathrm{e}}, \mathrm{L}_{\mathrm{a}}\right)
\end{aligned}
$$

When planning the required number of experiments for the response function - by planning a multifactorial experiment of type $2^{4}$ by the Box-Wilson method, it is necessary to make a regression equation. In the study of the process of forming the seam took into account the influence of the following parameters of the welding mode: $I$ - welding current strength; $U-$ arc voltage; $L_{a}-\operatorname{arc}$ length $\left(L_{a}=L_{a}+\right.$ $+f_{d}$, where $f_{d}$ - exciting effects along the length of the arc caused by the characteristics of the surfacing surface); $V-$ welding speed; $V_{w}$ - the feed rate of the filler wire; $d_{e}-$ the diameter of the tungsten electrode; $d_{w}$ - wire diameter, $\mathrm{mm}$. When choosing the ranges of variation of the factors of functions provided by the experimental plan, the results of modeling the heating process and the possibility of reproducing such levels in practice were taken into account, [27].

It was assumed that for the equipment used $d_{e}$ and $d_{w}$ were selected according to the recommendations [1], and $d_{e}=2,5 \mathrm{~mm}$, та $d_{w}=3 \mathrm{~mm}$, and the arc voltage was provided by the adopted inverter model Fronius MagicWave $3000, U=10.1-22 \mathrm{~V}$. The values of the factors taken into account are given in table. 1 . To conduct planning on the
Table 1. Levels of factors and intervals of variation

\begin{tabular}{|c|c|c|c|}
\hline \multirow{2}{*}{ Factors } & Marking & \multicolumn{2}{|c|}{$\begin{array}{c}\text { Levels of change of } \\
\text { factors }\end{array}$} \\
\cline { 2 - 4 } & & -1 & +1 \\
\hline $\mathrm{X}_{1}-$ amperage, A & $I$ & 155 & 215 \\
\hline $\mathrm{X}_{2}-$ arc length, mm & $L_{a}$ & 3 & 7 \\
\hline $\begin{array}{c}\mathrm{X}_{3}-\text { welding speed, } \\
\mathrm{mm} / \mathrm{sec}\end{array}$ & $V$ & 2,78 & 4,2 \\
\hline $\begin{array}{c}\mathrm{X}_{4}-\text { wire feed } \\
\text { speed, mm/sec }\end{array}$ & $V_{w}$ & 6 & 9 \\
\hline
\end{tabular}

Table 2. Experiment planning matrix

\begin{tabular}{|c|c|c|c|c|}
\hline $\begin{array}{c}\text { № of } \\
\text { experiment }\end{array}$ & $\mathrm{X}_{1}$ & $\mathrm{X}_{2}$ & $\mathrm{X}_{3}$ & $\mathrm{X}_{4}$ \\
\hline 1 & - & + & - & + \\
\hline 2 & - & - & + & + \\
\hline 3 & + & - & - & - \\
\hline 4 & + & - & + & - \\
\hline 5 & - & + & - & - \\
\hline 6 & - & - & - & + \\
\hline 7 & - & + & + & - \\
\hline 8 & - & - & - & - \\
\hline 9 & - & + & + & + \\
\hline 10 & + & + & + & + \\
\hline 11 & + & - & - & + \\
\hline 12 & + & + & - & + \\
\hline 13 & + & - & + & + \\
\hline 14 & + & + & - & - \\
\hline 15 & - & - & + & - \\
\hline 16 & + & + & + & - \\
\hline
\end{tabular}

basis of a full-factor experiment of type $2^{4}$ a matrix of experiment planning was compiled, which is given in table 2 [6]. As a result of plans realization of experiment the regression equations allowing to estimate influence of the factors, which were taken into account on effective parameters $h, e, g, \chi$ are received.

From the Pareto diagram it is seen that the greatest influence on the height of the welded roller $h$ has the speed $v$, the wire feed speed and the total effect of these two factors. With increasing speed $v$ the height of the weld will decrease, and with increasing wire feed speed $v_{w}$-increase. Increasing the current $I$, the length of the arc $L_{a}$ leads to a slight decrease in the height of the seam, table. 3.

The width of the weld roller is influenced by three factors: the length of the $\operatorname{arc} L_{a}$, the speed $v$ and the current I. The greatest influence is the length of the arc and the speed of movement. From the Pareto diagram shown in table 3, it is seen that the greatest influence on the depth of the melt of the roller have the length of the arc, velocity and current. With increasing arc length and velocity, the depth of penetration of the weld decreases, and with increasing current-increases. 
Table 3. The results of statistical processing of experimental data

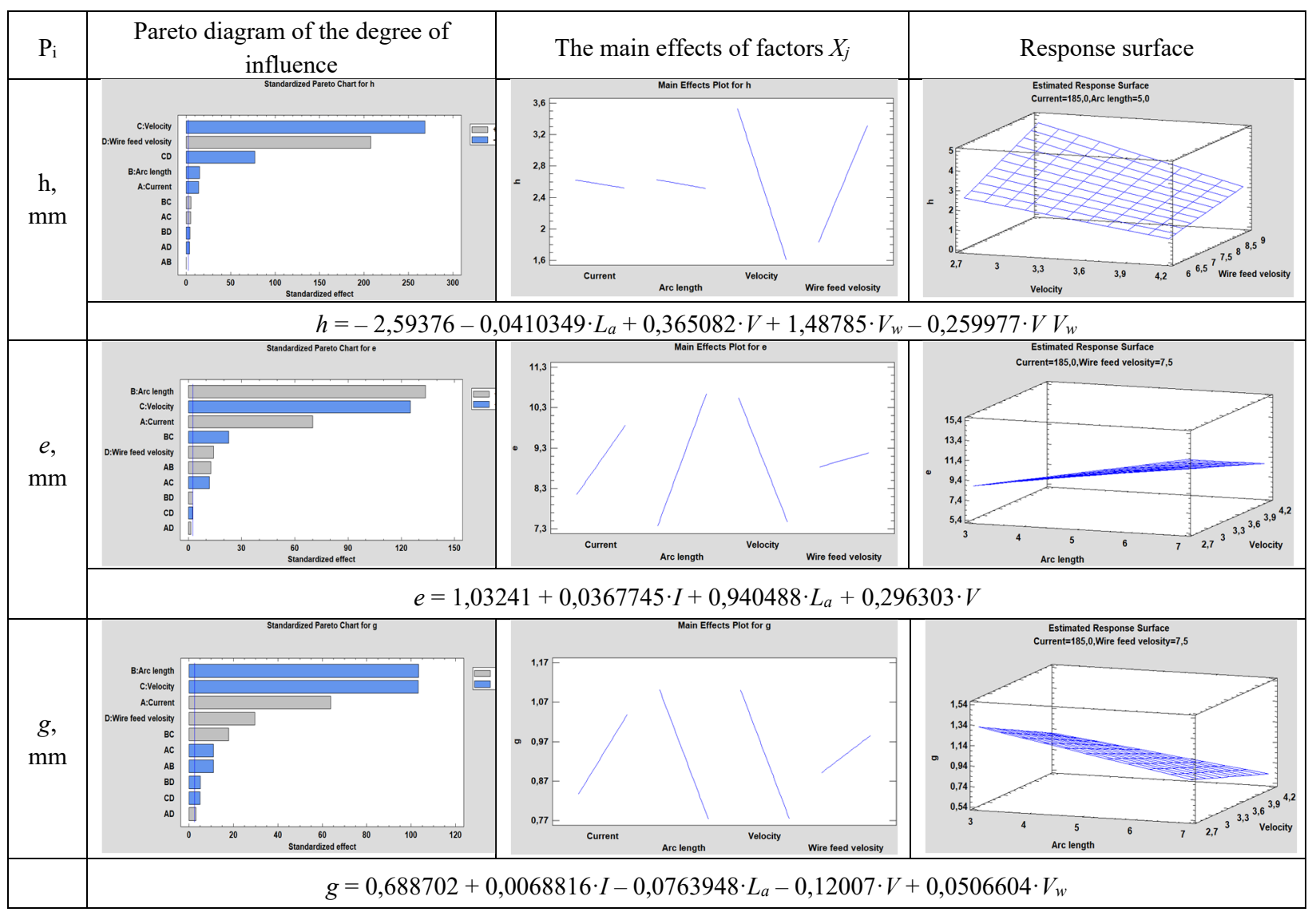
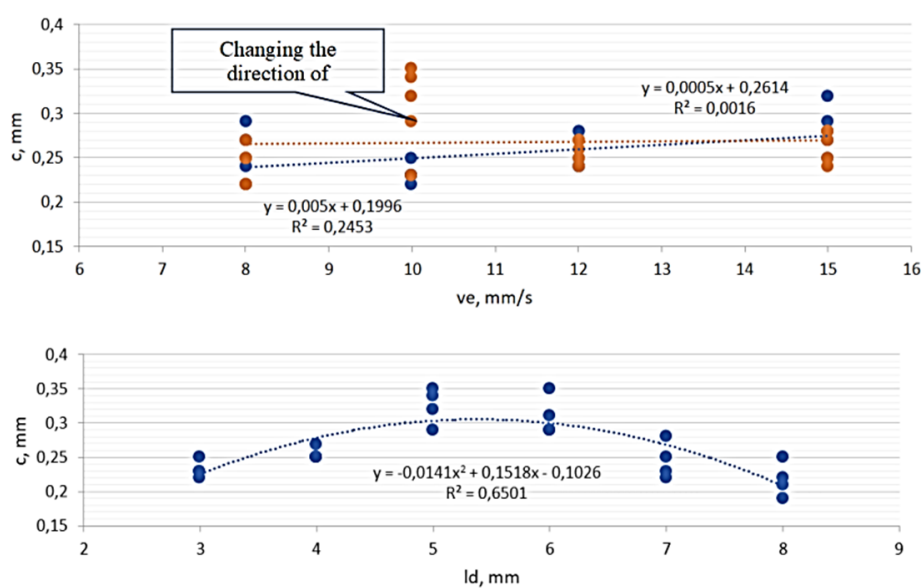

Fig. 7. Change of the parameter $\chi, \mathrm{mm}$, depending on the speed of the head, $v \mathrm{~mm} / \mathrm{sec}(a)$ and the length of the $\operatorname{arc} L_{a}(b)$.

The last line of table.3. shows the response surface of the objective function-the depth of penetration of the weld $g, \mathrm{~mm}$, and their two-dimensional cross sections in the planes of the impact parameters, which can clearly illustrate the dependence of this parameter $g$ on individual factors $-I, L_{a}, V$.

The level of undulation was rather weak from the conditions of processing, see Fig. 7. It was found that the maximum values of $\chi, \mathrm{mm}$, acquires at the initial moment of time (when the arc is ignited) and when the arc is turned off. Significant perturbation can be considered a change in the conditions of movement of the head: so when you change the direction of movement associated with the formation of certain layers of the reproducible model, the ripple increases; a decrease in the parameter $\chi$ is observed at steady motion.

Microelectronic study of the cross section of the seam proves that under conditions of relatively low speeds of the head (up to $10-15 \mathrm{~mm} / \mathrm{sec}$ ) the laying of rollers is quite dense (Fig. 8, $a, b$ ). In this case, when shifting the trajectories of the head (Fig. 5, $b$, option 2), the density is the highest, otherwise the cavities are significant and close to the cavities when laying plastic (Fig. 8, c). On the right microphoto (fig. $8, b$ ) separate microcavities and defects of connection of layers are observed. These correspond to the results given in [28].

However, a comparison of interlayer and inter-roller laying of materials by FDM-process and WAAM-process proves that the density in the latter case is up to $97 \%$ of the 


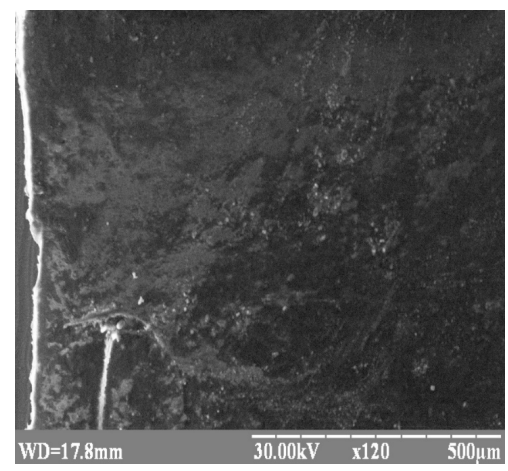

$a$

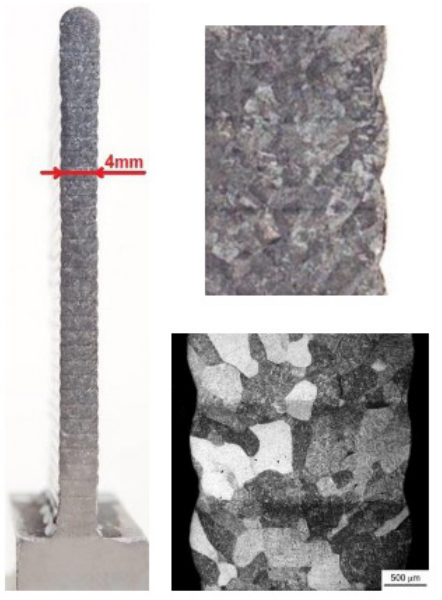

1-bead, Y-Z plane

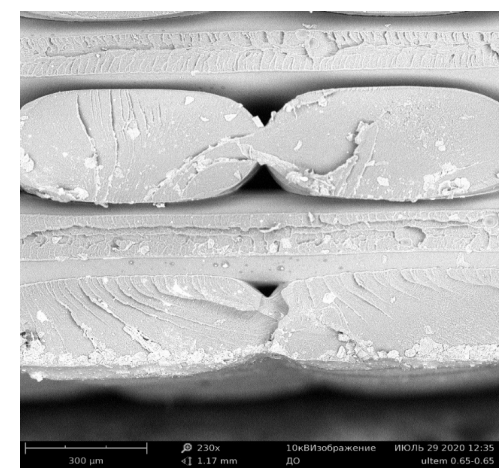

$b$

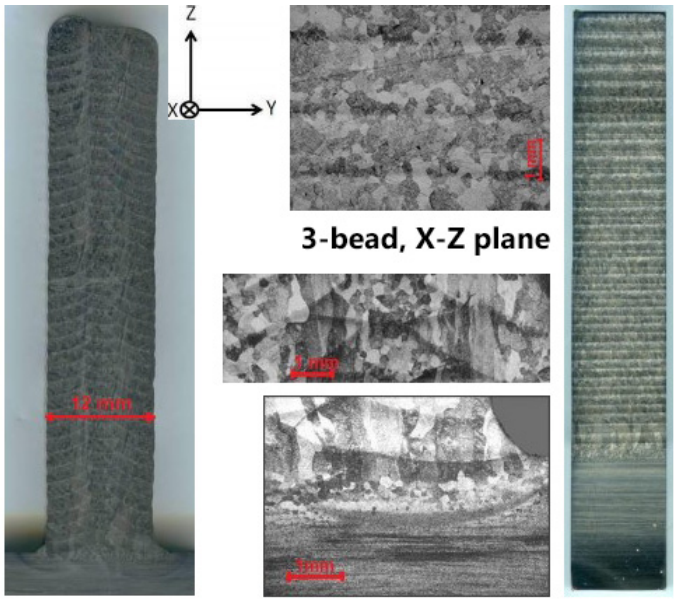

3-bead, Y-Z plane

c

Fig. 8. Comparison of end sections of model fragments obtained by surfacing $(a)$, FDM-printing with plastic $(b)$ and additive technology xBeam 3D Metal Printing $(c)$. Microphoto $(b)$ - ULTEM 9085 plastic, element created on the STRATAsys FORTUS 380 printer. Cavities and defects of the open end face are observed on the sections

density of the source material, while in WAAM the density can reach $99.2 \%$, Fig. $8, a$.

Thus, it can be stated that improving the quality of products obtained by processes based on argon-arc welding, is seen in the optimization of methods of forming rollers, in particular, providing appropriate overlap of trajectories on the layers of teaching by $0.25 e$, establishing a rational arc length, as well as maintaining the mode of dynamic constancy of arc combustion. Further research should be aimed at determining the patterns of solidification of the metal in the melt bath, as well as to study the dynamic phenomena of wave processes under the action of a system of forces during the formation of the surfacing roller.

\section{Conclusions}

A set of theoretical and experimental studies aimed at improving the quality of products created by the WAAM process. It is shown that this process can be successfully used for the manufacture of single workpieces for further machining by traditional methods. Due to the application of the multifactor experiment planning method, a regression equation is obtained, which allows to determine the main parameters of the roller formed by argon-arc welding from the main process parameters-arc length, current, head speed and wire feed rate.

It was found that the height of the weld is most affected by speed, wire feed speed and a combination of these factors. The width of the weld is most influenced by the length of the arc, speed and current, and these factors have the greatest impact on the depth of penetration of the weld. The influence of these factors on the undulation of the roller surface is negligible; it is concluded that the parameter $\chi$ results in dynamic phenomena of wave processes that develop under the action of a system of forces during the formation of the surfacing roller. Improving the quality of products is seen in the optimization of methods of forming rollers, ensuring dynamic constancy of the working head, ensuring appropriate overlap of trajectories in the layers by $0.25 e$, ensuring dynamic constancy of the working head, establishing a rational arc length and maintaining dynamic combustion constancy arc.

The response surfaces of objective functions in the planes of influence parameters are constructed, which allow to visually illustrate the dependence of the controlled geometrical parameters of the seam on individual influence parameters. 
It is shown that the improvement of product quality, first of all, by reducing the surface roughness, is possible by optimizing the methods of forming rollers, in particular, providing appropriate overlap of trajectories on the layers by $0.25 \mathrm{e}$, arc, as well as maintaining the mode of dynamic constancy of arc combustion.

\section{References}

[1] J.G. Zhou and Z.Y. He, “A new rapid tooling technique and its special binder study,” Rapid Prototyping J., Vol.5, Issue 2, pp. 82-88, 1999. https://doi.org/10.1108/13552549910267461

[2] S.N.A. Majid et al., "Influence of Integrated Pressing during Fused Filament Fabrication on Tensile Strength and Porosity, ” $J$. of Mechanical Engineering, Vol. 2, pp. 185-195, 2017.

[3] M.A. Nazan et al., "Optimization of warping deformation in open source 3D printer using response surface method," in Proc. of Mechanical Engineering Research Day, pp. 71-72, 2016.

[4] V. Sharma and S. Singh, "Rapid Prototyping: Process Advantage, Comparison and Application," Int. J. of Computational Intelligence Research, Vol. 12, No.1, pp. 55-61, 2016.

[5] D. Nimawat and M. Meghvanshi, "Using Rapid Prototyping Technology in Mechanical Scale Models," Int. J. of Engineering Research and Applications, Vol. 2, Issue 2, pp. 215-219, 2012.

[6] V.N. Sidorets et al., "Features of electrode melting in arc welding of steels", Electrical Engineering and Electromechanics, No. 2, pp. 34-37, 2013.

[7] M.R. Alkahari et al., "Melt Pool and Single Track Formation in Selective Laser Sintering / Selective Laser Melting," Advanced Materials Research, Vol. 933, pp. 196-201, 2014. https://doi.org/10.4028/www.scientific.net/AMR.933.196

[8] H.A. Habeeb et al., "Strength and porosity of additively manufactured PLA using a low cost 3D printing", Proceedings of Mechanical Engineering Research Day, 2016, pp. 69-70.

[9] I.V. Pentegov et al., "To the analytical determination of the melting coefficient in arc welding of steels", Bulletin of ChSTU. Technical Sciences Series, No. 2 (57), pp. 89-96, 2012.

[10] S. Jhavar, N.K. Jain, and C.P. Paul, "Developement of microplasma transferred arc ( $\mu$-PTA) wire deposition process for additive manufacturing applications," J. of Materials Processing Technology, Vol. 214, No. 5, pp. 1102-1110, 2014. https://doi.org/10.1016/j.jmatprotec.2013.12.016

[11] J. Xiong, G.J. Zhang, and W.H. Zhang, "Forming appearance analysis in multi-layer single-pass GMAW-based additive manufacturing," The Int. J. of Advanced Manufacturing Technology, Vol. 80, Issues 9-12, pp. 1767-1776, 2015. https://doi.org/10.1007/s00170-015-7112-4

[12] J. Xiong and G.J. Zhang, “Adaptive control of deposited height in GMAW-based layer additive manufacturing,” J. of Materials Processing Technology, Vol. 214, Issue 4, pp. 962-968, 2014. https://doi.org/10.1016/j.jmatprotec.2013.11.014

[13] B.Q. Cong et al., "A Comparative Study of Additively Manufactured Thin Wall and Block Structure with Al-6.3\% Cu Alloy Using Cold Metal Transfer Process," Applied Sciences, Vol. 7, p. 275, 2017. https://doi.org/10.3390/app7030275

[14] Y. Ma et al., "Effect of interpass temperature on in-situ alloying and additive manufacturing of titanium aluminides using gas tungsten arc welding," Additive Manufacturing, Vol. 8, pp. 71-77, 2015. https://doi.org/10.1016/j.addma.2015.08.001

[15] I.V. Pentegov et al., "Change in the melting coefficient of a coated welding electrode during its heating and melting during arc welding of steels without short circuits," Visnyk ChSTU. Technical Sciences Series, No 3 (59), pp. 110-120, 2012.

[16] I.V. Pentegov et al., "Melting of a coated welding electrode during arc welding of steels with short circuits", Bulletin of ChSTU. Technical Sciences Series, No 1 (63), pp. 93-103, 2013.

[17] D.H. Ding, et al., "Adaptive path planning for wire-feed additive manufacturing using medial axis transformation," J. of Clenaer Production, Vol. 133, pp. 942-952, 2016. https://doi.org/10.1016/j.jclepro.2016.06.036

[18] G. Venturini et al., "Optimization of WAAM deposition patterns for T-crossing features," Procedia CIRP, Vol. 55, pp. 95-100, 2016. https://doi.org/10.1016/j.procir.2016.08.043

[19] S. Kapil et al., "Hybrid-layered manufacturing using tungsten inert gas cladding," Progress in Additive Manufacturing, Vol. 1, Issues 1-2, pp. 79-91, 2016. https://doi.org/10.1007/s40964-016-0005-8

[20] I.V. Pentegov et al., "Melting of the coated welding electrode during underwater arc welding", Bulletin of ChSTU. Technical Sciences Series, No 4 (69), pp. 65-75, 2013.

[21] W. Aiyiti et al., "Investigation of the overlapping parameters of MPAW-based rapid prototyping," Rapid Prototyping J., Vol. 12, Issue 3, pp. 165-172, 2006. https://doi.org/10.1108/13552540610670744

[22] C.S. Wu, L. Wang and W.J. Ren, "Plasma Arc Welding: Process, Sensing, Control and Modeling," Manufacturing Processes, Vol. 16, pp. 74-85, 2014. https://doi.org/10.1016/j.jmapro.2013.06.004

[23] M.S. Sawant and N.K. Jain, "Characteristics of Single-Track and Multi-track Depositions of Stellite by Micro-plasma Transferred Arc Powder Deposition Process,” J. of Materials Engineering and Performance, Vol. 26, Issue 8, pp. 4029-4039, 2017. https://doi.org/10.1007/s11665-017-2828-y

[24] B. Cong, J. Ding and S. Williams, "Effect of arc mode in cold metal transfer process on porosity of additively manufactured Al-6.3\% Cu alloy," The Int. J. of Advanced Manufacturing Technology, Vol. 76, Issues 9-12, pp.1593-1606. https://doi.org/10.1007/s00170-014-6346-x 
[25] V.N. Sidorets et al., "Features of electrode melting in arc welding of steels", Electrical Engineering and Electromechanics, No. 2, pp. 34-37, 2013.

[26] J. Mehnen et al., "Design for Wire and Arc Additive Layer Manufacture," in Proc. of the 20th CIRP Design Conf., 2010. Organization and mathematical planning of the experiment, Ekaterinburg, Ural University Press, 2018.

[27] I.V. Pentegov et al., "Change in the melting coefficient of a coated welding electrode during its heating and melting during arc welding of steels without short circuits," Visnyk ChSTU, Technical Sciences Series, No. 3 (59), pp. 110-120, 2012.

[28] I.V. Pentegov et al., "Melting of a coated welding electrode during arc welding of steels with short circuits", Bulletin of ChSTU, Technical Sciences Series, No. 1 (63), pp. 93-103, 2013.

[29] N.A. Rosli, et al., "Design and development of a low-cost 3D metal printer," J. of Mechanical Engineering Research and Development, No. 3, Vol. 41, pp. 47-54, 2018. https://doi.org/10.26480/jmerd.03.2018.47.54

[30] P. Kazanas et al., "Fabrication of geometrical features using wire and arc additive manufacture," in Proc. of the Institution of Mechanical Engineers, Part B: J. of Engineering Manufacture, pp. 1042-1051, 2012. https://doi.org/10.1177/0954405412437126

[31] Available: https://stc-paton.com/services/razrabotka-i-vnedrenie-energosberegayushhix-i-konkurentosposobnyix-texnologijsvarki,-naplavki,-vosstanovleniya,-naneseniya-zashhitnyix-pokryitijzi-i-elektrometallurgii.html

\title{
Покращення якості виробів, створених адитивними технологіями на основі аргонно-дугового зварювання
}

\author{
О. Ф. Саленко, А. О. Костенко, Д. О. Цуркан, О. В. Самойленко, О. О. Ченчева, В. Т. Щетинін
}

Анотація. В роботі розглядаються питання отримання мінімальної хвилястості поверхонь, ияо формуються аддитивним процесом аргонно-дугового зварювання. Відомо, щчо геометричні параметри валика розплаву, щцо пошарово формує відтворювану заготовку, визначаються як енергетичними, так і кінематичними характеристиками процесу. При иььому викладання валиків відбувається з оптимальним перекриттям, завдяки чому вдається досягти максимальної щільності моделі, однак з одночасним виникненням певної хвилястості, обумовленої термодинамічними явищами у ванні розплаву. Запропонована модель формування валику наплаву, завдяки якій встановлено раціональні умови викладання шарів. Наведено експериментальні дослідження прочесу аргонно-дугового відтворення моделей заданої форми, отримано регресійні рівняння для визначення контрольованого параметру хвилястості.

Показано, щуо на параметр хвилястості випливають динамічні явища та хвильові процеси, які розвиваються під дією системи сил під час формування валику наплаву. Покращення якості виробів вбачається в оптимізації способів формування валиків, забезпеченням динамічної сталості руху робочої головки, забезпеченням відповідного перекриття траєкторій руху по шарам викладання на величину 0,5е, забезпеченням динамічної сталості руху робочої головки, встановленням раціональної довжини дуги, а також підтриманням режиму динамічної сталості горіння дуги

Побудовано поверхні відгуків цільових функцій в площчинах параметрів впливу, які дозволяються наглядно проілюструвати залежність контрольованих геометричних параметрів шва від окремих параметрів впливу

Ключові слова: аргонно-дугове зварювання, адитивні прочеси, якість, точність форми, поверхневий иар.

\section{Улучшение качества изделий, полученных аддитивными процессами на основе аргонно-дуговой сварки}

\author{
А. Ф. Саленко, А. О. Костенко, Д. О. Цуркан, О. В. Самойленко, О.О. Ченчева, В. Т. Щетинин
}

Аннотация. В работе рассматриваются вопросы получения минимальной волнистости поверхностей, формируемой аддитивными прочессами аргонно-дуговой сварки. Известно, что геометрические параметры валика расплава, которыми послойно формируется воспроизводимая заготовка, определяются как энергетическими, так и кинематическими характеристиками прочесса. При этом выкладка валиков происходит с оптимальным перекрытием, вследствие чего удается достичь максимальной плотности модели, однако с одновременным возникновением определенной волнистости, обусловленной термодинамическими явлениями в ванне расплава. Предложенная модель формирования валика расплава, использование которой позволило установить рациональны условия выкладки слоев. Приведень экспериментальные исследования процесса аргоннодуговой наплавки моделей заданной формы, получены регрессионные уравнения для определения контролируемого параметра волнистости.

Показано, что на параметр волнистости влияют динамические явления и волновые прочессы, которые развиваются под действием системы сил при формировании валика расплава. Улучшение качества изделий видится в оптимизачии способов формирования валиков, в обеспечении динамической устойчивости движения рабочей головки, обеспечением соответствуюшего перекрытия траекторий движения по слоям выкладки на величину 0,5е, установлением рациональной длины дуги, а также поддержанием режима динамической устойчивости горения дуги.

Построено поверхности отклика ијелевых функций в плоскостях параметров прочесса, которые дают наглядную иллюстрацию зависимости контролируемых геометрических параметров от режимов сварки

Ключевые слова: аргонно-дуговая сварка, аддитивны прочессы, качество, точность формы, поверхностный слой. 